\title{
Correction to : Hip osteonecrosis: stem cells for life or behead and arthroplasty?
}

\author{
Philippe Hernigou $^{1} \cdot$ Gildasio Daltro ${ }^{2} \cdot$ Jacques Hernigou $^{3}$
}

Published online: 23 June 2018

(C) SICOT aisbl 2018

\section{Correction to: International Orthopaedics https://doi.org/10.1007/s00264-018-4026-4}

There is an error in the original publication for the photos of the Guest Editors were not included. The publisher would like to apologize for any inconvenience this oversight may have caused.

The original article has been corrected.

The online version of the original article can be found at https://doi.org/ 10.1007/s00264-018-4026-4

$\triangle$ Philippe Hernigou

philippe.hernigou@wanadoo.fr

1 Hôpital Henri Mondor, 94010 Créteil, France

2 Federal University of Bahia, Salvador, Brazil

3 Epicura Hospital, Baudour and Hornu Belgium, Baudour, Belgium 